\title{
PENDAMPINGAN PEMBUATAN STUDENTS' BLOG SEBAGAI MEDIA PEMBELAJARAN BAHASA INGGRIS
}

\author{
Budianto Hamuddin*1, Dahler ${ }^{2}$, Indah Muzdalifah ${ }^{3}$, Syaifullah ${ }^{4}$ \\ Universitas Lancang Kuning \\ e-mail: budihamuddin@gmail.com
}

\begin{abstract}
This present study share an innovative approach to review the implementation of a blogging activity in two different semester students listed under English department of FKIP Unilak in Indonesia. Blogs, which are interactive homepages that are easy to set up and manage, enable students to engage in online exchanges, thereby expanding their language study and learning community beyond the physical classroom. Regular blogging also encourages more autonomous learning. Findings from an attitudinal survey conducted over two semesters with nine classes of 127 students who follow blog based class and 18 students from co-curricular group who joined the workshop demonstrate that they had extremely positive and supporting perception toward both blog as the media or strategy in their classes.
\end{abstract}

Keywords - Perception, Blog, Student

\section{ABSTRAK}

Artikel ini berbagi hasil evaluasi dari sebuah pendekatan inovatif yang coba diterapkan di jurusan bahasa Inggris FKIP Unilak, dimana persepsi pengguna blog yakni mahasiswa di dua semester yang berbeda akan menjadi titik fokus dalam penelitian ini. Blog merupakan homepage interaktif yang mudah untuk dikelola memungkinkan siswa untuk terlibat dalam kegiatan online, sehingga memperluas kegiatan pembelajaran bahasa mereka melebihi jika belajar didalam kelas. Blogging bisa juga mendorong proses pembelajaran yang lebih otonom. Temuan dari survei sikap dan persepsi yang dilakukan selama dua semester dengan sebelas kelas dengan jumlah mahasiswa sebanyak 168 akan tetapi dalam masa pengumpulan data dari angket online terdapat 145 mahasiswa yang mengisi angket yang terdiri dari 127 mahasiswa jurusan bahasa Inggris serta 18 mahasiswa dari group ekskul Blogger yang terdiri dari jurusan yang berbeda-beda. Dari hasil analisis data menunjukkan bahwa mereka memiliki persepsi yang positif dan mendukung penggunaan blog sebagai media atau strategi pembelajaran peningkatan kemampuan bahasa Inggris di dalam kelas mereka.

Kata kunci-Persepsi, Blog, Mahasiswa

\section{PENDAHULUAN}

Indonesia sebagai negara berkembang semakin dituntut untuk mengikuti perkembangan arus globalisasi dunia. Salah satunya adalah perkembangan dalam bidang Information technology (IT). Berbagai fasilitas, kualitas dan manfaat yang ditawarkan oleh IT didesain untuk memudahkan manusia dalam mengakses berbagai informasi. dan memudahkan siapa saja untuk belajar dimana saja, kapan saja, dan dari siapa saja. Saat ini hampir tidak ada aktivitas atau profesi yang tidak berhubungan dengan IT termasuk dunia pendidikan. Penggunaan IT seperti internet dan blog dapat dimanfaatkan sebagai sarana dan media pembelajaran dibidang pendidikan.

Pemanfaatan teknologi seperti internet dan blog telah memberi manfaat yang sangat besar dalam proses belajar-mengajar dan dari dari tahun ke tahun, trends peningkatan jumlah pemilik dan penulis di blog atau blogger semakin meningkat dari berbagai lapisan dan institusi pendidikan, termasuk mahasiswa di jurusan jurusan bahasa Inggris FKIP Unilak yang menggunakan blog sebagai sarana belajar alternatif meningkat sangat signifikan dalam kurun waktu 2 tahun terakhir ini (Hamuddin: 2016). Trend peningkatan ini terjadi karena blog telah digunakan sebagai media pembelajaran 
alternatif dibeberapa mata kuliah seperti Reading, Structure, Intro to Linguistic, Semantic dan Moprho-syntax.

Sejauh ini penggunaan blog di beberapa mata kuliah tersebut digunakan untuk memposting tugas seperti article review, slide presentase maupun multimedia. Proses pembelajaran di beberapa mata kuliah tersebut juga menunjukkan bahwa blog tidak hanya mampu menjadi ajang melatih kemampuan writing dan reading dalam ELT context, akan tetapi juga mampu menjadi sarana untuk menghantarkan mahasiswa lebih up to date dengan artikel dari penelitian-penelitian terbaru berkenaan dengan tugas yang mereka kerjakan (Hamuddin, 2016).

Akan tetapi, tak dapat dipungkiri bahwa sebuah proses pembelajaran pasti memiliki tantangan dan problematikannya masing-masing, begitu pula dengan proses pembelajaran yang menggunakan blog sebagai media pengajaran. Oleh karena itu, untuk membantu memaksimalkan proses dan hasil pembelajaran dijurusan bahasa Inggris FKIP Unilak, tulisan ini mencoba mencoba mencari tahu persepsi mahasiswa dibeberapa mata kuliah yang berbasis blog sekaligus mengukur dan mencari tahu persepsi mahasiswa terhadap penggunaan blog sebagai media pengajaran dan pembelajaran dengan judul: "Persepsi Mahasiswa Terhadap Blog Sebagai Media Pembelajaran di Jurusan Bahasa Inggris FKIP Unilak". Yang dilaksanakan di jurusan Bahasa Inggris FKIP Unilak.

\subsection{Blog Sebagai Media Pembelajaran}

Kata media berasal dari bahasa Latin medius dan merupakan bentuk jamak dari kata medium yang secara harfiah berarti perantara atau pengantar. Dalam bahasa Arab, media adalah perantara Yakni, perantara atau pengantar pesan dari pengirim kepada penerima pesan. Blog atau yang awalnya berasal dari kata weblog secara umum pengertiannya adalah sebuah situs web yang mudah dibuat dan mudah diperbarui sekaligus menyediakan wadah bagi seorang penulis atau banyak orang penulis untuk bisa menerbitkan dengan seketika ke dunia maya. Oleh karena itu penggunaan media blog dalam pendidikan agar sistem pembelajaran yang ada semakin inovatif dan berkembang. Fauzan, (2009)

Perkembangan yang ada memang tidak hanya berdampak positif saja, namun membawa dampak yang negatif pula bagi lingkungan, sikap, pemikiran dan kehidupan. Setiap orang pasti bergerak ke arah kemajuan di mana segala sesuatunya menjadi sangat cepat dan mudah. Pendidikan merupakan hal mendasar yang harus dimiliki oleh setiap orang tanpa terkecuali. Pendidikan bukan hanya pendidikan pada sektor-sektor yang berkaitan, namun juga meliputi berbagai institusi pendidikan yang ada. Pendidikan juga bukan hanya sekedar mencari ilmu di sekolah atau institusi pendidikan lain, namun meliputi segala bentuk pendidikan dalam kehidupan, misalnya pendidikan yang dilakukan oleh orang tuanya dalam mengajari anaknya yang masih kecil makan, minum, belajar bagaimana bersikap sopan dan sebagainya.

Pendidikan merangkumi berbagai hal dan melalui berbagai media. Guru maupun dosen sekarang ini dituntut memiliki kreativitas dan selalu berinovasi dalam proses pendidikannya. Begitu juga halnya dengan perkembangan teknologi internet yang perlu dan dapat dimanfaatkan sebagai media pembelajaran. Selain itu internet juga menyediakan fasilitas transaksi produk, tranformasi ilmu dan life style. Sebagian besar orang di dunia sudah bisa menggunakan internet untuk mencari informasi yang mereka inginkan, contohnya blog. blog sangat beragam mulai dari sekedar meningkatkan keahlian mengetik ataupun hanya sekedar hobi saja, tapi yang jelas blog memiliki kegunaan yang tidak bisa disepelekan. Dalam perkembangannya banyak sekali artikel yang terposting dan kenyataanya bisa membantu para pencari lewat search engine seperti google. Blog dengan desain yang baik pastinya dimiliki oleh para blogger yang memiliki kemampuan dalam merangkai bahasa mesin, namun agak disayangkan karena kemampuan ini tidak banyak orang yang memilikinya.

Demikian juga interaksi antara peserta didik dengan dosen/guru maupun antara sesama peserta didik. Peserta didik dapat saling berbagi informasi atau pendapat mengenai berbagai hal yang menyangkut pelajaran ataupun kebutuhan pengembangan diri peserta didik. Guru, dosen atau instruktur dapat menempatkan bahan-bahan belajar dan tugas-tugas yang harus dikerjakan oleh peserta didik di tempat tertentu di dalam web untuk diakses oleh para peserta didik sesuai dengan kebutuhan, guru/dosen dapat pula memberikan kesempatan kepada peserta didik untuk mengakses bahan belajar tertentu maupun soal-soal ujian yang hanya dapat diakses oleh peserta didik sekali saja 
dan dalam rentangan waktu tertentu pula.

\subsection{Blog Sebagai Media Penyampai Informasi}

Adapun kegunaan Blog untuk dunia pendidikan adalah blog sebagai media penyampai informasi dari guru kepada murid atau dosen kepada mahasiswanya, karena blog sifatnya online maka penyampaian informasi diharapkan merata. Serta bagi siswa atau mahasiswa dapat mengirimkan tugas-tugas kepada guru kapan saja dan dimana saja. Dengan adanya blog dari guru atau dosen kita dapat mengakses bahan-bahan belajar setiap saat dan berulang-ulang. Selain itu kita juga dapat berkomunikasi dengan guru/dosen setiap saat, misalnya melalui chatting dan email. Mengingat sumber belajar yang sudah dikemas secara elektronik dan tersedia untuk diakses melalui internet, maka kita dapat melakukan interaksi dengan sumber belajar ini kapan saja dan dari mana saja, juga tugas-tugas pekerjaan rumah dapat diserahkan kepada guru/dosen begitu selesai dikerjakan.

\section{Workshop dan Pendampingan Pembuatan Students' Blog}

Kajian ini sadar dengan adanya Blog akan mampu mempermudah interaksi antara peserta didik dengan bahan/materi pelajaran. Oleh karena itu dilaksanakanlah Workshop pembuatan students blog dilaksanakan di awal semester ganjil tahun ajaran (Maret) 2016 dan dilanjutkan dengan pendampingan pengelolaan students' blog selama dua semester dan berakhir pada (Desember) 2016. Oleh karena melalui studi ini evalusi dilakukan untuk melihat hasil dari kegiatan tersebut melalui angket persepsi mereka.

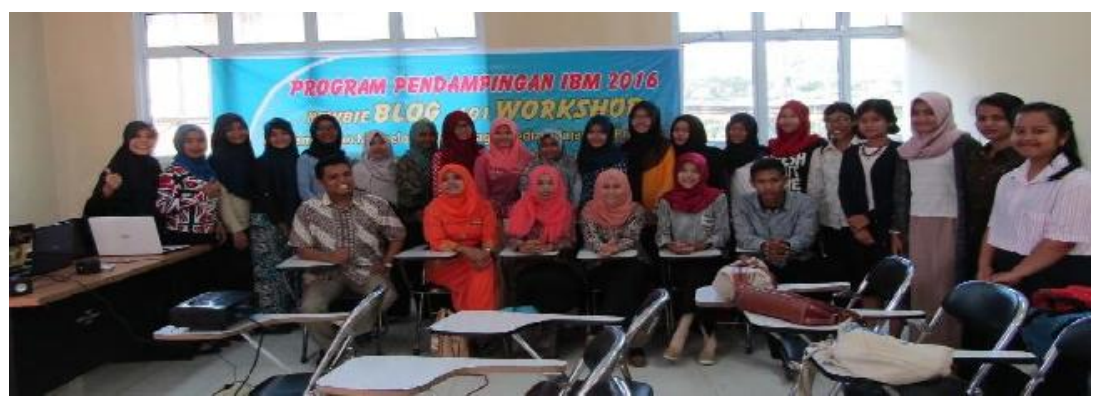

Figure 1. Workshop pembuatan blog students

Artikel ini menggunakan pendekatan deskriptif quantitatif dengan memfokuskan pada persepsi mahasiswa yang telah mengikuti workshop dan pendampingan pembuatan students' blog sebagai media untuk meningkatkan kemampuan berbahasa Inggris mereka sekaligus media publikasi tulisan ilmiah maupun non-ilmiah mereka selama 2 semester tersebut.

\section{METHODOLOGY}

Dalam kajian kualitatif, sampel disebut sebagai nara sumber, partisipan atau informan. Sugiyono (2008). Dalam artikel ini, informanya adalah 164 mahasiswa yang memiliki blog (blogger) atau mahasiswa yang mengikuti kelas yang berbasis blog dibeberapa matakuliah di jurusan Pendidikan Bahasa Inggris FKIP Unilak di dua semester yang berbeda yakni semester 2 dan semester 4 dimana mahasiswa di semester ini merupakan pilot project dalam penggunaan IT di FKIP Unilak. Metode pengambilan sampel yang digunakan dalam kajian ini untuk pengisian angket online adalah total sampling dengan harapan mampu menggambarkan respon mahasiswa lebih luas.

Pengumpulan data dalam kajian ini menggunakan angket (online) dimana pengumpulan data dilakukan dengan menyebarkan angket secara online untuk mencari tahu persepsi mahasiswa yang mengikuti workshop pendampingan pembuatan students' blog sebagai media untuk meningkatkan kemampuan berbahasa Inggris mereka sekaligus media publikasi tulisan ilmiah maupun non-ilmiah mereka. Hal ini juga dilakukan untuk melihat dan menyikapi penggunaan blog didalam proses pembelajaran di beberapa mata kuliah berbasis blog di jurusan bahasa Inggris FKIP Unilak.

Angket pada kajian ini mulai didistribusikan sejak 15 April - 15 Desember 2016 kepada 168 mahasiswa yang memiliki blog (blogger) atau mahasiswa yang mengikuti kelas yang berbasis blog 
dibeberapa matakuliah di jurusan Pendidikan Bahasa Inggris FKIP Unilak di dua semester yang berbeda yakni semester 2 dan semester 4 .

Lalu, data yang diperoleh melalui online akan di analisis secara quantitative tentang persepsi dan kecenderungan dari responden, pada kajian ini. Kajian ini mengembangkan konsep dan menghimpun fakta, tetapi tidak melakukan pengujian hipotesa (Widodo, 2008). Data artikel ini menggunakan teknik statistik deskriptif analisis berdasarkan hasil survey dan akan dilaporkan dalam bentuk tabulasi frekuensi maupun prosentase. Analisis dalam kajian ini bertujuan melakukan pengukuran terhadap fenomena sosial yakni persepsi para blogger terhadap penggunaan blog sebagai media pengajaran.

\section{HASIL DAN TEMUAN}

Berdasarkan data yang masuk sejak angket dibuka pada bulan April-Mei 2016, sebanyak $145(88 \%)$ orang mahasiswa semester 2 dan semester 4 FKIP bahasa Inggris yang telah mengisi angket dari total 164 responden yang di harapkan berpartisipasi di dalam kajian ini. Data dibawah ini menunjukkan total responden berdasarkan jenis kelamin.

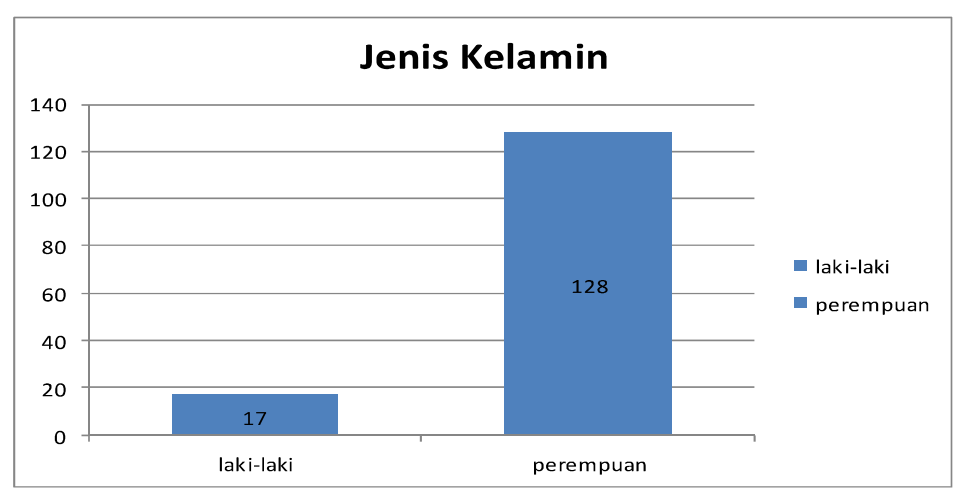

Chart 4.1 Respondedn berdasarakan Gender

Dari 128 responden yang mengisi angket secara online di dapati $86 \%$ adalah perempuan dengan jumlah 128 orang, sementara sisanya 17 orang (12\%) adalah laki-laki. Dari data diatas dapat dilihat bahwa mayoritas mahasiswa semester 2 dan semester 4 pengguna blog (blogger) prodi pendidikan bahasa Inggris FKIP Unilak yang mengambil bagian pada survey ini adalah perempuan. Hal ini merupakan refleksi kuantitas yang menunjukkan bahwa mahasiswa perempuan lebih dominan dari segi kuantitas di prodi bahasa Inggris FKIP Unilak dan mereka adalah blogger yang aktif.

\subsection{Kebermafaatan kegiatan workshop dan Pendampingan pembuatan students' blog}

Data tersebut berdasarkan analisis kuantitatif pada jawaban di pertanyaan "Apakah workshop dan Pendampingan pembuatan students' blog bermanfaat bagi anda...?".

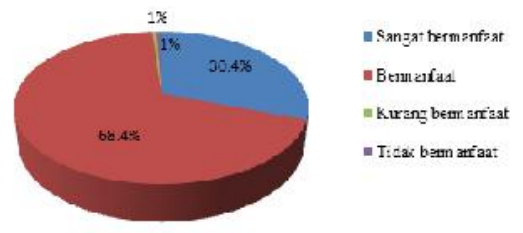

Chart 4.2 Manfaat kegiatan workshop dan Pendampingan pembuatan students' blog

Data kuantitatif dari mayoritas responden $(98,8 \%)$ menunjukkan persepsi yang positif berkaitan dengan harapan mereka mengikuti kegiatan ini. Mayoritas memberikan jawaban memberikan 
manfaat yang besar bagi mereka. Jawaban ini merupakn respon positif terhadap penyelenggaran kegiatan tersebut berdasarkan persepsi mereka.

\subsection{Fungsi blog dalam mempublikasi tulisan mahasiswa}

Pada pertanyaan "Saya .... Bahwa mahasiswa harus belajar mempublikasikan tulisan ilmiah baik itu dijurnal ilmiah maupun di framework berbasis publikasi seperti Blog maupun sejenisnya. Chart 4.3 dibawah ini menjelaskan lebih rinci.

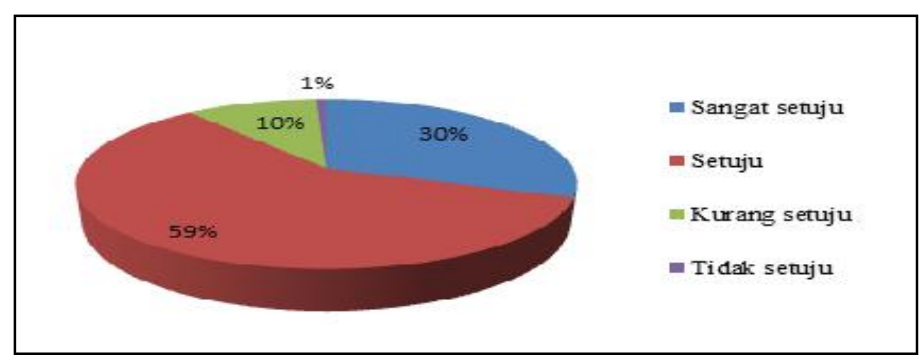

Chart 4.3 belajar mempublikasikan tulisan melalui blog

Data pada chart 4.3 diatas memberikan gambaran bahwa sebagian besar $86,1 \%$ responden setuju untuk belajar bagaimana mempublikasikan tulisan ilmiah. Lalu pada pertanyaan berikutnya "Setiap mahasiswa harus tahu bagaimana dan dimana bisa mempublikasikan tulisan (non)ilmiah walau lewat students blog" Ditunjukkan bahwa mayoritas $57 \%+15 \%$ atau mayoritas respoden $(72 \%)$ menyadari bahwasanya bahwasanya publikasi ilmiah itu penting bagi mahasiswa. Seperti yang ditampilkan pada chart 4.3 dibawah ini.

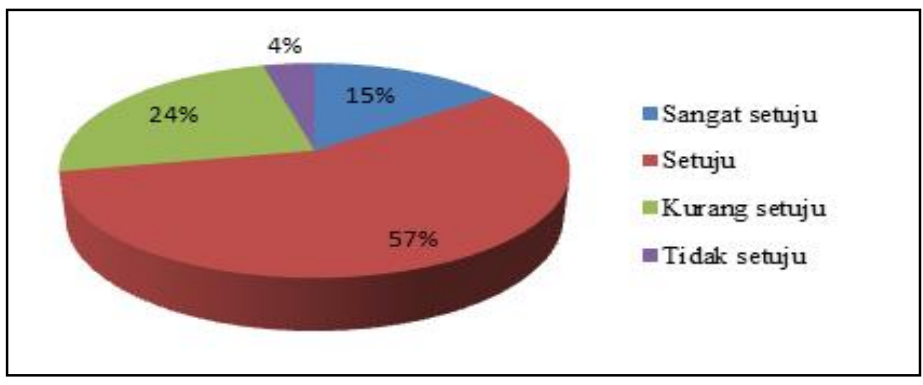

Chart 4.4 kesadaran mahasiswa untuk mempublikasikan tulisan melalui blog

Data pada angket juga menemukan temuan yang menarik bahwa "Chart 4.5 dibawah ini menggambarkan persentase responden tersebut.

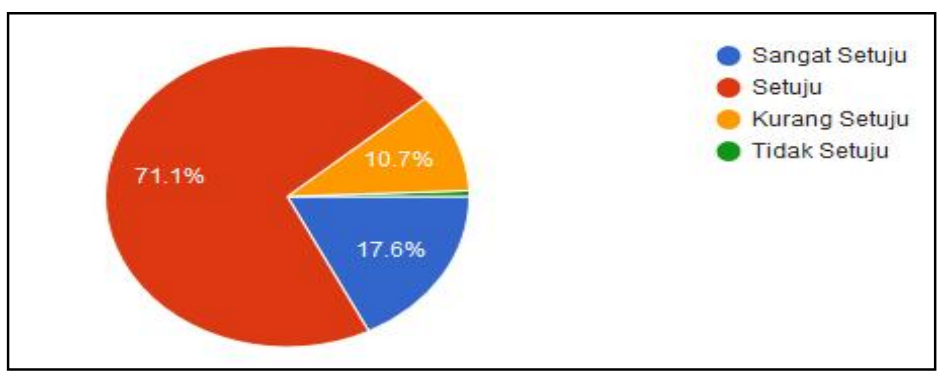

Chart 4.5 Pentingnya Memiliki blog dan mempublikasikan tulisan

Mayoritas mahasiswa tenyata sadar bahwa memiliki students' blog dan bisa mempublikasikan tulisan serta tugas-tugas mereka untuk di baca khalayak ramai itu juga penting. Data pada table 4.5 
diatas menggambarkan bahwa mayoritas responden juga tahu bahwa memiliki "students' blog itu penting" karean bisa membantu untuk mempublikasikan tulisan-tulisan serta tugas kuliah mereka.

\subsection{Efektisiftas acaraworkshop dan pendampingan pembuatan students' blog}

Dalam penelitian ini menemukan fakta bahwa hampir semua responden baik yang menjawab setuju maupun sangat setuju $(88,7 \%)$ dari responden pada penelitian ini mempunyai pandangan positif terhadap penggunaan workshop dan pendampingan pembuatan students' blog . Lalu berdasarkan pertanyaan no. berikutnya "Saya merasa, workshop dan pendampingan ini meningkatkan pengetahuan saya dalam hal blogging publikasi ilmiah"

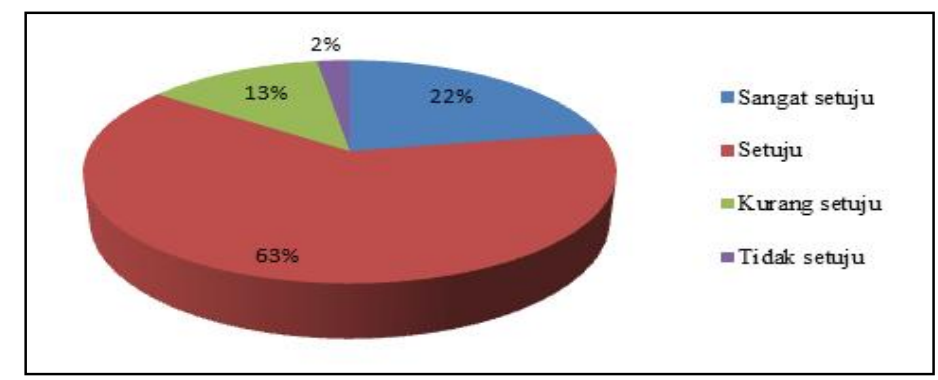

Chart 4.5 Efektifitas acara seminar dan pendampingan pembuatan blog students'

Persepsi positif dari mayoritas responden tergambarkan cukup jelas di chart 4.5 diatas bahwa belajar publikasi ilmiah melalui kegiatan workshop dan pendampingan sangat efektif dalam meningkatkan pengetahuan serta memberikan efek positif dalam peningkatan, hal ini berdasarkan persepsi responden pada analisis kuantitatif di penelitian ini. Mayoritas responden memberikan jawaban yang positif tentang efektifitas kegiatan tersebut.

\section{KESIMPULAN}

Artikel pada kajian ini menggunakan pendekatan deskriptif analitis. Berkenaan kegiatan workshop dan dan pendampingan pembuatan blog students'. Menggunakan Instrument angket online berdasarkan data dapatan dari 127 orang mahasiswa semester 2 dan semester 4 FKIP bahasa Inggris ditambah 18 orang anggota dari ekskul blogger FKIP Unilak yang telah berpartisipasi di dalam kajian ini. Dari 145 responden yang mengisi angket secara mayoritas (98\%) memiliki persepsi bahwa kegiatan ini sangat bermanfaat bagi mahasiswa untuk meningkatkan kemampuan bahasa Inggris untuk mahasiswa sekaligus membantu mereka melakukan publikasi tulisan mereka. Melalui kegiatan seminar dan pendampingan pembuatan blog students', mereka sadar efektifitas dari blog bisa berfungsi sebagai media pembelajaran dan publiaksi (97\%). Selama menggunakan blog dalam mata kuliah mereka (96\%.) menunjukkan hal yang positif.

Hal tersebut menunjukkan bahwa kegiatan ini sangat pas untuk diterapkan di Prodi bahasa Inggris berdasarkan persepsi mahasiswa yang telah mengikuti kegiatan ini. Persepsi mahasiswa pada kajian ini juga menunjukkan mayoritas mahasiswa (88\%) merasakan manfaat dari kegiatan ini dan memberikan kesempatan yang lebih terbuka untuk lebih mendalami bahasa Inggris baik didalam maupun di luar ruang-ruang kelas pembelajaran di prodi bahasa Inggris FKIP Unilak melalui publikasi tulisan di students blog

\section{DAFTAR PUSTAKA}

[1] Ariyanto, Dede, Blogspot Hacking Modifikasi Blogspot dan Aksesorinya, Yogyakarta: Andi Offset. 2009.

[2] Asnawir dan Basyiruddin Usman, Media Pembelajaran, Jakarta: Ciputat Pers. 2002. 
[3] Asrori, Mohammad, Psikologi Pembelajaran, Bandung: Wacana Prima.2008.

[4] Aydin, Selami. "The Use of Blogs in Learning English as a Foreign Language." Online Submission 4.1 (2014): 244-259.

[5] Beale, Russel "Blogs, reflective practice and studentcentered learning", dalam British Computer Society,Vol. 2 (37 September 2007), UK: Lancaster University.2007.

[6] Efendi, Agus, Refolusi Kecerdasan Abad 21, Bandung: Alfabeta, 2005.

[7] Fauzan, Akhmad, The Use of Blog to Improve Students' Writing Skills in Developing Example Essays at the English Education Study Program, Palangka Raya University (Tesis, Universitas Negeri Malang, Malang.2009)

[8] Hamuddin, Budianto, Indah Muzdalifah, and Dahler. "Blogs as Powerful Learning Tools: The Perception from EFL Students in Indonesia." Open Science Framework, 2 Jan. 2018. Web.

[9] Hamuddin, Budianto. "Using blog to Promote English Skills for EFL Students: The Students' Perception." ELT-Lectura 3.2 (2016).

[10] Hamuddin, Budianto, and Indah Muzdalifah. "Identification of Common Problems in Blogging Based Class at PBIG FKIP Unilak." ELT-Lectura 4.1 (2017).

[11] Noytim, Usa. "Weblogs enhancing EFL students' English language learning." Procedia-Social and Behavioral Sciences 2.2 (2010): 1127-1132.

[12] Samples, Bob Revolusi Belajar untuk Anak: panduan Belajar Sambil Bermain untuk Membuka Pikiran Anakanak Anda,terjemah: Rahmani Astuti Bandung: Kaifa, 1999. 